\title{
剪断力を受ける溶接継手の低温における強度（I）*
}

\author{
一試験温度の影響一
}

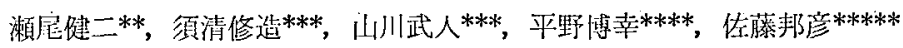

\section{Strength of the Welded Joints on which Shear Force is Applied at Low Temperature (Part I)*}

-Effect of Temperature on Strength of Welded Joint-

by Kenji Séo**, Shuzo Susei***, Taketo Yamakawa***, Hiroyuki Hirano**** and Kunihiko Satoh*****

The present research deals with the fracture behavior and the strength of welded joints such as a side fillet welded joint which is loaded parallel to the axis of the weld at low temperature.

In this paper, the effect of temperature on the fracture behavior in these welded joints are investigated experimentally.

Experiments are made with five types of welded specimen in a temperature range from $20^{\circ} \mathrm{C}$ to $-170^{\circ} \mathrm{C}$. In the series of experiment, the results obtained are as follows:

1) Three different types of fracture mode are appeared according to the different temperature.

2) It is cleared that the critical shear displacement which depends on temperature can be applied as the engineering fracture criteria for fracture of these welded joints.

3) In these welded joints, small scale of fractures of weld metal by shear force at low temperature induce the fatal brittle fracture of base metal.

\section{1. 緒}

\section{言}

溶接構造物の脆性破塙に関する研究は従来汃ら多くな されている122.しかしそれらの研究のほと九ごは作為啲

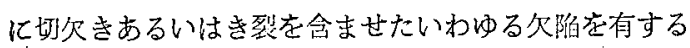
突合せ継手に引張りあるいは曲げ荷重が加わる埸合を対 象として行なわれてきた。

しかし俸用の溶接篟造物では突合世継手以外に，例え ば船款棈造におけるロンジ材のビルトアップ溶按，トラ ンス材のスティフナー，ブラケットフェイスの取り㑬け 溶接，また建築構造におけるボックス柱のダイヤフラム 溶接などいわゆるする肉溶接継手あるいは部分とけてみ 溶接継手が多く存在し，てれらは主として愬断荷重を受 ける場合が多い：そしててれらの継手では欠陥がなくて

\footnotetext{
*原稿受付 昭和55年7月30日（昭和50年度秋季全国大会に一発俄）

**正 筫 姫路工燥大学 Member, Himeji Institute of

$\therefore$ ***正 員 㥓重工業(侏) Member, Kawasaki Heavy Ind$\therefore \quad$ ustries Co., Ltd.

****学 生員 大阪大学大学䟚 (現在石川帛播碑重工業(株)) Student Member, Graduate School of Osaka Univerity (Present Address; Ishikawajima Harima Heayy Industries Co., Itd).

*****正 只一阪大学工学部 Member, Faculty of Engineering, Osaka University
}

む, 次陷と同じ作朋をする不溶着部が存在し，また溶接 端部は剕造的不速続となり大きな剪断応力集中を生じ る.そのためとのような継手は溶接が完全に施工された

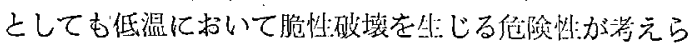
れる。

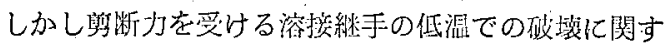
る研究はほとんど行なわれておらず，数少ない例として 太四の研栄が挙げられる3).太四は側面すみ肉溶接継手

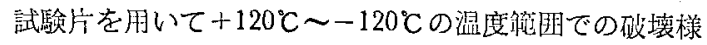
相を調べている，そしてー $60^{\circ} \mathrm{C}$ までの眸度では継手の剪 断強度は低下することはないが，それ以下の温度では母 材部で脆性破填を生じ，いわゆる母材部の引張強度がす み肉溶接継手の剪断強度より低くなるためする肉溶接継 手の剪断強度を求めることが出来なかったと報告してい る.しかしすみ肉溶接継手の脚辰, 溶接長, 每材部寸法 などを变化させた実験は行なっでおらず，てのような継 手の低温における強度を十分明らか比したとはいい難 い.

本研笁は剪断力をうりる溶接継手の低混における強度 におよほす温度，継手形式，継手部寸洁などの影郘を明 らかにするととを目的として行なった：…… 本報告では SM50B 材を用いた側面すみ肉溶接継手お 
Table 1 Chemical compositions and mechanical properties of base plate

\begin{tabular}{c|c|c|c|c|c|c|c|c}
\hline \hline & \multicolumn{4}{c|}{ Chemical compositions (\%) } & \multicolumn{2}{c}{ Mechanical properties } \\
\hline \multirow{2}{*}{ SM50B } & $O$ & $\mathrm{Si}$ & $\mathrm{Mn}$ & $\mathrm{P}$ & $\mathrm{S}$ & Y.S. $\left(\mathrm{kg} / \mathrm{mm}^{2}\right)$ & T.S. $\left(\mathrm{kg} / \mathrm{mm}^{2}\right)$ & $\mathrm{E} 1 .(\%)$ \\
\hline
\end{tabular}
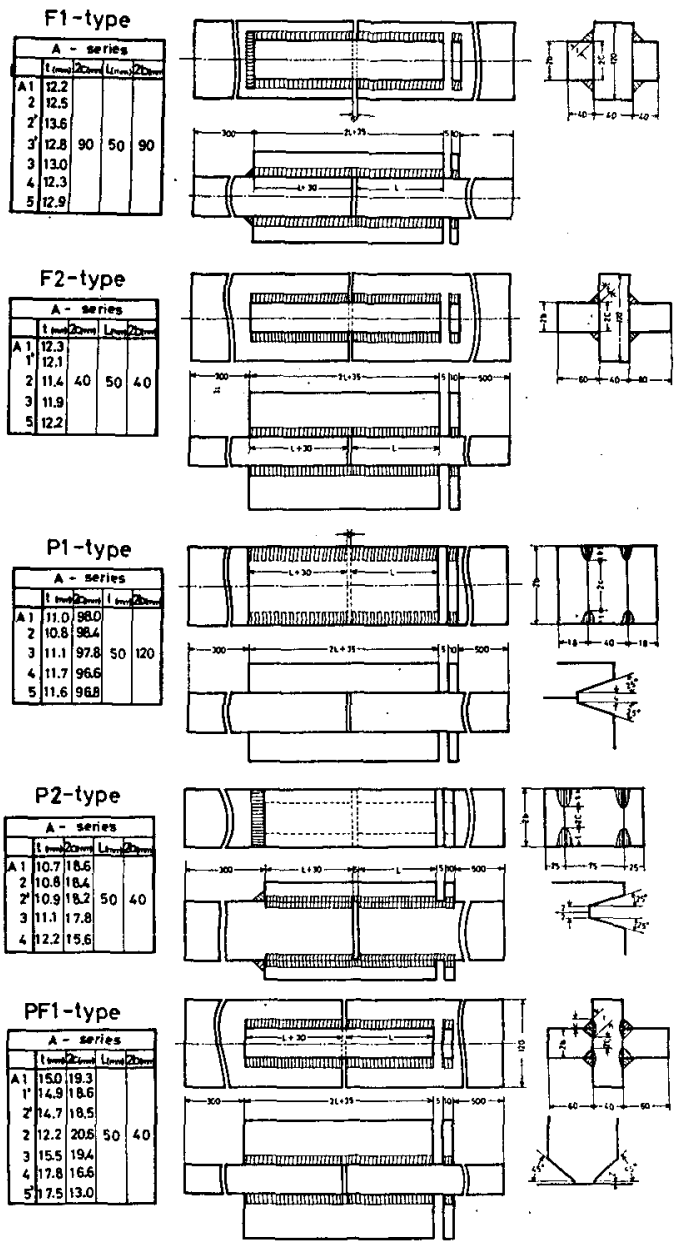

Fig. 1 Dimensions of specimens

よび部分にとけとみ溶挨継手試験片の常温からー170 $\mathrm{C}$ までの広い温度範四におりる破壊様相を観察し，䋛手の．

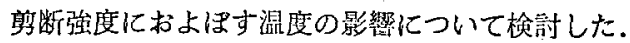

\section{2. 実験}

\section{1 供試材および試験片形状}

板厚 $40 \mathrm{~mm}$ の SM50B 材 (材料の化学組成と機械的 性兵を Table 1 に示す) を用い, Fig. 1 亿示す 5 程類の 形状の試験片を製作した。試験片 F 1，F２は側面すみ
肉谘接継手, P 1, P 2 は部分とり乙み溶接継手, PF 1 は 補強すみ肉を有する部分とけとみ溶接継手である。

試験片の溶按は $4 \mathrm{~mm} \phi$ 低水素系 $50 \mathrm{~kg}$ 級溶接棹（溶 着金属の降伏強さ $41 \sim 49 \mathrm{~kg} / \mathrm{mm}^{2}$, 抗張力 $51 \sim 59 \mathrm{~kg}$ / $\mathrm{mm}^{2}$ ) を用い, 電流 $170 \pm 5$ [A], 電生 22 23 [V], 速 度 $150 \sim 160 \mathrm{~mm} / \mathrm{min}$ の溶接条件で手溶接で行なった。 なお P 1，P 2,PF 1 試験片はそれぞれ Fig. 1 に示す形状 の開先をとって溶接した，また問題を簡単にするためす へての陚験片について主板と侧板の間は $1 \mathrm{~mm}$ 程度の間 隔をあけて溶接を行ない, 両板の摩擦の影響が現われな いようにした、なお通常のすみ肉溶接では間隔を設けな いが，との場合発生する主板と側板の摩擦は強度上は安 全側として作用するであろう。

溶接後主板，側板には各々 Fig. 1 に示すような約 5 $\mathrm{mm}$ 巾の切久きを入れ所定の溶接長にし，試験部に溶接 の終始端が入らないようにした，溶接長 $(L)$ およびの ど厚 $(t)$ は Fig. 1 に示す值を規定值とした。しかし溶 接部には溶接後何の処理むほどとしていないのでのど厚 は各々の試験片で 1 2 $\mathrm{mm}$ 程度のばらつきを持ってい た. それ故実験紹果の整理には各々の䞒験片の試験後に 测定した実のど厚を用いた。

\section{2 実 験 方 法}

試験片の引張りは 200 ton 電子管式万能試験機を䍏 い, $-170^{\circ} \mathrm{C} \sim 20^{\circ} \mathrm{C}$ の試験温度で行なった. 試験片の冷 却はPhoto 1 に示すように冷却槽を試験片のまわりに 2 段〜 3 段によりつけとれに液体窒䒺を注入して行なっ た.試験片の温度は Fig. 2 に示すように前むって予想さ れる破壊発生位置 6 点に CC 熱電対を取り付けて測定し た.そして泠却槽内に液体空素がなくなりかつ温度測定 部 6 点の温度が均一になった状態で载荷した。そして破 液発生時の破壊部の温度をむって試験温度とした。载荷 開始から破壊発生までの温度上帠は 5 ○以下であった。 剪断变位の测定は Fig. 2 亿示す2箇所で表面から $5 \mathrm{~mm}$ の位圈によりつけたクリップゲージにより行なった。こ の㜪断変位は主板，側板の変北をあ含んだ值であるので 敩泌には溶接部の剪断変位とは異なるが，予備実験の結 果今回使朋した試験片では主板および側板の変北は溶接 部の変形に比へて無視出来るととを確認したのでての剪 断变位をすって溶接部の剪断变位 $\delta$ とした。 


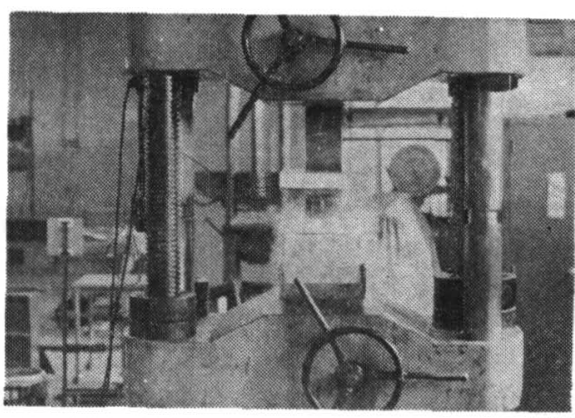

Photo 1 Experimental appareatus

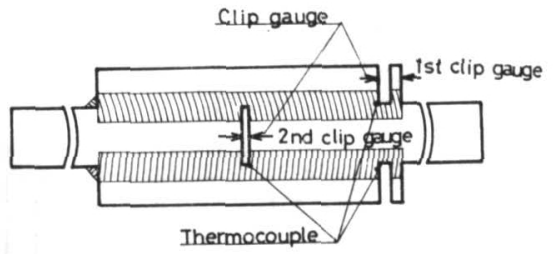

Fig. 2 Measurement of temperature and shear displacement

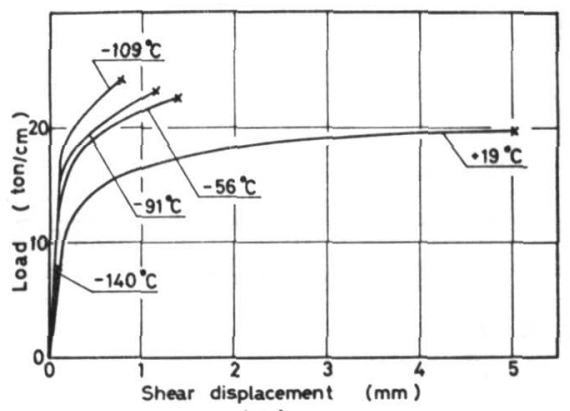

(a)

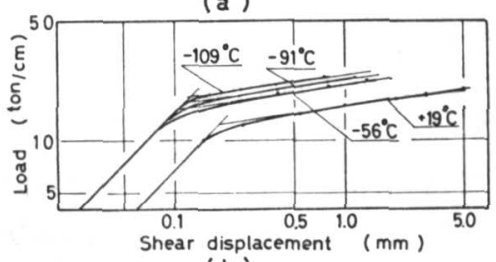

(b)

Fig. 3 Effect of temperature on load-shear displacement

\section{3. 荷重一剪断変位曲線におよぼす温度の影響}

各試験温度において荷重増加にともなう剪断変位の変 化の一例を Fig. 3 (a) に示す. 困はF 1 試験片の結果で ある.困の縦軸は単位溶接長当りの剪断力を, 横軸は岦 断変位量を示している. 本実験では第1クリップゲージ と第 2 クリップゲージはほとんど同じ値を示したので第 1クリップゲージの值を剪断変位量として示した.

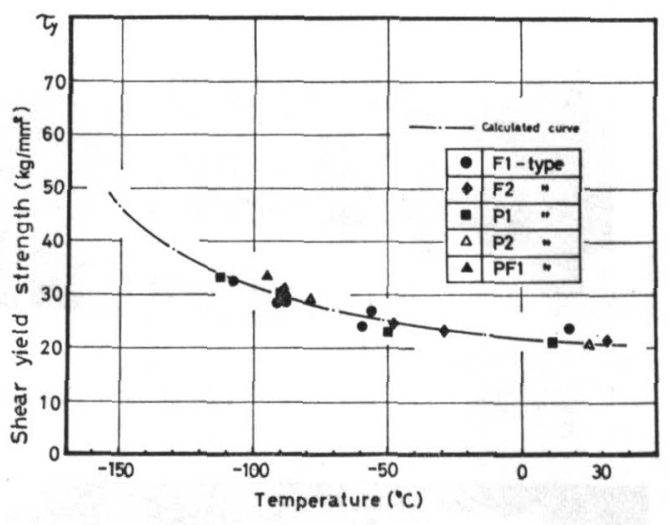

Fig. 4 Rellation between temperature and shear yield strength

荷重が低い間は剪断変位量 $\delta$ は荷重に比例して增加 するが, 荷重が高くなり溶接部が降伏すると $\delta$ は急增 する. そして試験温度が低くなるととあに荷重一剪断変 位曲線は高くなりまた破断までの剪断変位は小さくな る. Fig. 3 の荷重一剪断変位の関係を両対数グラフに示 すと Fig. 3 (b) の如く二本の直線となる.との二本の直線 の交点が降伏を示し, その時の剪断力を剪断降伏力 $\left(T_{y}\right)$ と考えるととができる. 本実験では各試験片ののど厚に かなりのばらつきがあるため, 顡断降伏力を各試験片の のど厚で除し剪断降伏応力 $\left(\tau_{y}\right)$ を求めた。 その值を温 度に対してプロットしたのが Fig. 4 である. 䇂断降伏応 力は試験片形状には影響されず Arrhenius 型の温度依 存性を持つ(1)式で表わされる. 図の曲線は(1)式による值 を示している.

$$
\tau_{y}=\tau_{y_{0}} \operatorname{Exp}\{N(1 / T-1 / 273)\}
$$

$\tau_{y_{0}}: 0{ }^{\circ} \mathrm{C}$ に求ける剪断降伏応力 $\left(22.5 \mathrm{~kg} / \mathrm{mm}^{2}\right)$

$N$ : 定数 $(162 \mathrm{~K}), T:$ 絶対温度 $(\mathrm{K})$

また Fig. 3 より荷重一剖断変位は(2)式で表示できる.

$$
T=F \cdot \delta^{n}
$$

$T:$ 単位溶接長当りの剪断力

$\delta:$ 剪断変位

ここで(2)式における $n$ は Fig. 3 (b) の直線の傾きで本実 験の場合, 弾性域では $n=1$, 塑性域では $n=0.13$ で武 験片形状, 試験温度には影響されていない。 また係数 $F$ は試験片形状および試験温度によって異なり，とれにつ いては第 2 報で考察する.

\section{4. 破 壊 様 相}

\section{1 破壊樣相におよぼす温度の影響}

種々の試験温度における破壊の一例を Photo 2 亿示 す. 写真は PF 1 試験片の結果である. 常温の場合は写 


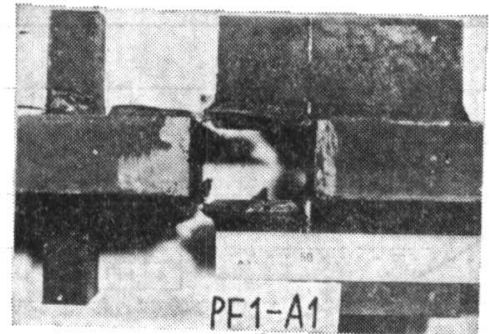

(a)

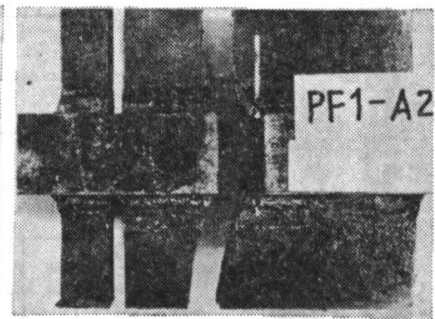

(b)

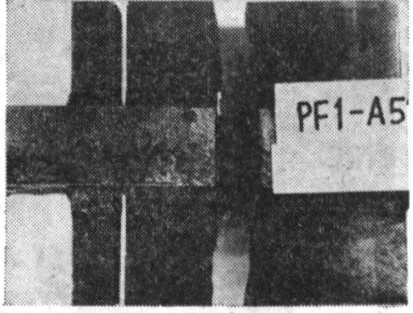

(c)

Photo 2 Fracture aspect of specimen PFI

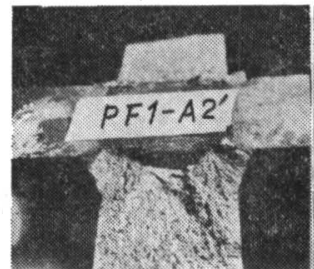

(a)

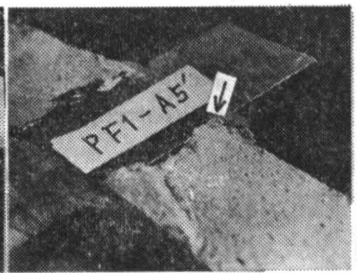

(b)
Photo 3 Example of fracture texture

真(a)の如く溶接部で剪断延性破壊（本報告では A-Type 破壊と呼ぶ）を生じる。しかし試験温度が低くなったー $39^{\circ} \mathrm{C}$ の場合は写真(b)に示すように, すみ肉溶接線上の主 板断続部から荷重軸に約 $45^{\circ}$ 方向に発生したき裂が側板 へ伝播し, 側板が荷重軸にほほ垂直に破壞（B-Type 破 壊）する。 この破壊は Photo 3 (a) 亿示すように巨視的 に脆性破面を示し, 破壊が溶接ルート部から荷重軸に対 して $45^{\circ}$ 方向に発生し, 側板に伝播した様相がよく現わ れている.さらに試験温度が低くなった $-140^{\circ} \mathrm{C} の$ 場合 はP Photo 2 (c) に示すように側板で荷重軸に対してほほ 垂直に脆性破壊（C-Type 破壊）を生じる。乙の種の破 壊は B-Type 破壊と異なり, 溶接端部に荷重軸と $45^{\circ}$ 方 向に生じるき裂は認められない, C-Type 破壊は Photo 3 (b) に示すように, き裂は溶接ルート部ではなく溶接止 端部 (矢印で示す) すなわち構造的不連続部から発生し ており, B-Type 破壊とは異なっている.

\section{2 限界剪断変位量と破壊様相}

破壊までの剪断変位量（限界剪断変位量）を温度に対 してプロットしたのが Fig. 5 である. 罒中記号に○印を 付けたものは A-Type 破壊を, 仰を付けたあのは BType 破壊を，無印は C-Type 破壊をしたものである. 限界剪断変位量之試験温度の関係は試験片 Type にかか わらずそれぞれの破壊様式に対応して三本の直線で表わ される.すなわち A-Type 破壊の場合はほぼ一定值を 示すが, B-Type 破壊では限界剪断変位量は温度の低下 ととむにほぼ指数関数的に低下する．そしてその値は(3)

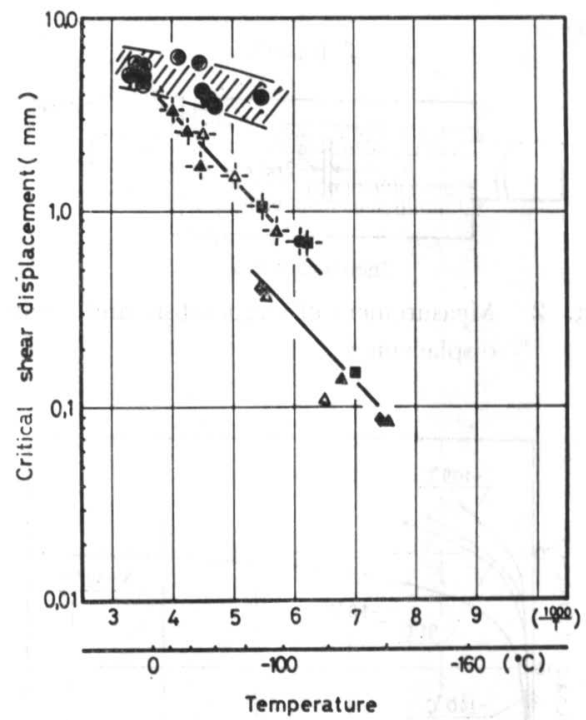

Fig. 5 Effect of temperature on critical shear displacement

式で表わされる.

$$
\begin{aligned}
& \delta_{c r}=4.0 \operatorname{Exp}\{785(-1 / T+1 / 273)\} \mathrm{mm} \cdots(3) \\
& T=\text { 絶刘温度 }(\mathrm{K})
\end{aligned}
$$

さらに温度が低下し -100 C 以下になり, C-Type 破壊が 生じると限界剪断変位量は B-Type の場合よりさらに 小さくなる．しかしこの場合も限界剪断変位量は温度低 下ととあに小さくなりその值は(4)式で表わすととができ る.

$$
\delta_{c r}=1.8 \operatorname{Exp}\{785(-1 / T+1 / 273)\} \mathrm{mm} \cdots(4)
$$

以上のととより剪断力をうりる溶揬継手の破壊様相は限 界剪断変位量によっても明確に三つの Type に区別でき る.

\section{5. 継 手強度}

\section{1 継手強度におよぼす温度の影響}

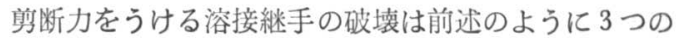




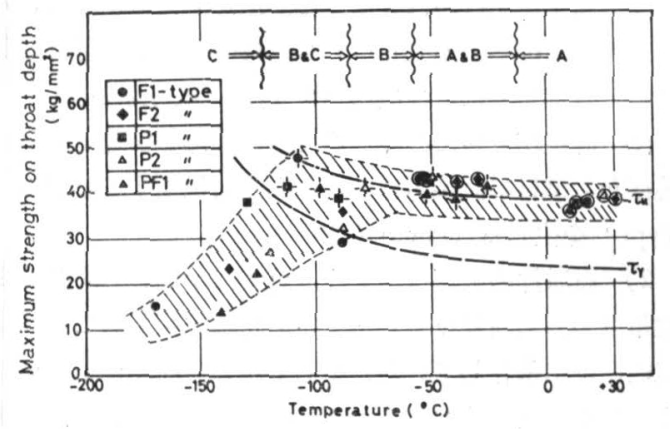

Fig. 6 Effect of temperature on maximum strength on throat depth

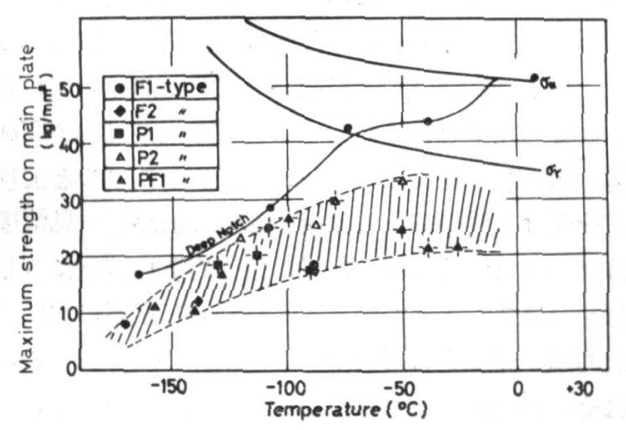

Fig. 7 Effect of temperature on maximum strength on main plate

Type となり，破壊が溶接部のみで生じる場合と側板あ るいは主板で生じる場合がある，そこで継手強度を溶接 部のど断面で考えるか，母材部断面で考えるかで破壊応 力值は異なる，そこでそれぞれの破壊様相に応じて継手 強度を検討する。

破壊荷重より溶接部のど断面を基準として求めた破壊 応力を Fig. 6 に示す. 図中記号に○印を付けたものはA -Type，- -印は B-Type，無印は C-Type 破壊をしたも のである、A-Type および B-Type 破壊をした場合, 破 壊応力は破壊様相にかかわらず温度低下之ともにゅるや 加に増加する㑯向を示し，ほぼ溶接金属の剪断強度 $\left(\tau_{u}\right)$ に等しい. しかし温度がさらに低下し C-Type 破壊を 生じると破壞応力は温度低下とともに急減し, 溶接金属 の降伏強度 $\left(\tau_{y}\right)$ より低くなる.な抢破壞応力は武験片 Type にはほとんど影響されていないようであるが，破 壊梯式の遷移する温度は継手形式により異なっているよ うである.

次に巨視的には母材部主板あるいは側板で破壊を生じ た B-Type, C-Type 破壊の場合について, 破壊荷重を 破壊を生じた母材部断面で除すととにより求めた破壊応 力を Fig. 7 亿示す. 記号は Fig. 6 の場合と同様である.

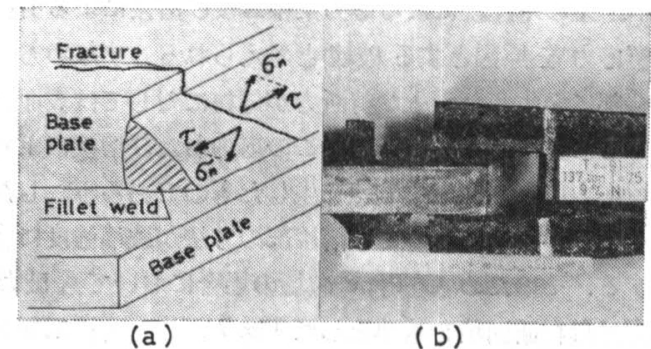

Fig. 8 Explanatory figure of crack initiation in B-type fracture

また図には母材の大型 Deep Notch 武験（板巾 $400 \mathrm{~mm}$, ノッチ深さ $120 \mathrm{~mm}$ ) 結果む示している。破壞応力值は かなりばらついているが, B-Type, C-Type いずれの 破壊の場合むかなり低応力の破壊となり, 鋭い切欠を有 する大型 Deep Notch 試験結果よりあ低くなっている. 本実験に用いた試験片の母材には切欠等の欠宿は含まれ ていないにもかかわらず Deep Notch 試験より低応力 破壊となったととは注目すべきととであろう．次にての 原因について考察する.

\section{2 破壊樣相と継手強度の関連}

まず B-Type 破壞に注目すると,この場合継手強度は 母材部応力に関しては低応力であるが, 溶接部応力で見 ると溶接金属の最大強度にほほ等しい. そして Photo 3 (a)に示した破面写真からわかるように，まず溶接部から 荷重軸に $45^{\circ}$ 方向に破壊が発生し, それが母材へ伝播し て完全破断となる．以上のとよより B-Type 破壊は次 のように考えられる.すなわち Fig. 8 (a) に示すように

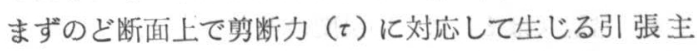
応力 $\left(\sigma_{n}\right)$ によって溶接端のルート部から高応力で脆性 的に破壊が発生する。 そしてその破壊が荷重軸に対して 垂直に近い角度で母材へ伝播し完全破断となったあので あろう。したがって母材応力が母材のき裂伝播停止応力 より小さい場合あるいは試験温度がき裂伝播停止温度よ り高い場合は B-Type 破壊は生じないであろう.とれを 確かめるため母材に $9 \% \mathrm{Ni}$ 鋼を用い, 同一溶接条件で F 1 試験片之同形状の試験片を製作しー $120^{\circ} \mathrm{C} て ゙$ 実験を 行なった. 継手強度はF 1 試験片とほほ等しい值を示 し, その破壊様相は Fig. 8 (b) 亿示すように, 溶接部で荷 重軸に対して $45^{\circ}$ 方向ののこ㐘状破壊となり主板あるい は側板の脆性破壊は見られなかった。 以上のととから上 述の推論の妥当性が確かめられる.

一方 C-Type 破壊は溶接部応力, 母材部応力のどちら に関しても低応力脆性破壊となっている，そして Photo 3 (b) に示す破壊写真からわかるように破壊は溶接端部の 構造上の不連続部から生じている，したがってての破壊 
は構造上の不連続による応力集中および溶接による引張 残留応力を原因とする破壇と考えられる，すなわち溶 接端部に発生した大きな剪断力が母材に対しては表面に 集中した剖断力として作用しての応力および溶接による 残留応力により低応力破壊を生じたものであろう。した がってての破壊においてあ溶接部の寸法が破壊強度に影 響する.そのため C-Type 破壊の場合においても破填 応力は母材断面積を基集とした Fig. 7 よりあ溶接部断面 積を基準とした Fig. 6 の方がばらつきが小さくなってい 万.

以上のてとより射断力を受りる溶按継手では溶接部寸 法が一見溶接部とは鱓関係と考えられる主板および側板 全体の低応力破壊に著しい影響をおよ淂す合があるこ とがわかる、すなわち常温においては構造的にそれほど 重要視しなくてあよいと考えられるような㰴断力をうけ る溶接継手であ，低温においてはその溶接部が破壊する ことにより構造的に重要な部材へ破壊が伝播し大事故に つながる危険性がある。したがって剪断力をうける溶接 継手を低温で使用する場合は上述のような破壊に対して 十分注意を払っておく必要があるう。

\section{6. 結䆑}

莮断力を受ける溶接継手の破壊举動および強度におよ

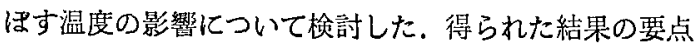
を次に示す。

1) 㷙惭力を曼ける泬接継手の破壊様相は試験温度に よって 3つの Type に別れる。すすなわち温度低下にとむ なって次のような破壊様相を示す。

(a) 常温又はそれに近い温度の場合は溶接部で剪断延 性破壊（A-Type）を生じる。 (b) 温度が比較的低くなると溶接部で荷重軸に対して $45^{\circ}$ 方向に䂭壊が発生しこれが母材へ伝播し，母材で荷 重軸にほほ垂苴に腹性破填（B-Type）を生じる。

(c) 温度がさらに低くなると溶接端部の棈造上の不連 続部から母材に直接脆性破壊が発生し伝播する破壊 (CType) を生じる (Photo 2 参照).

2）試験片の破壊は試験片 Type にかかわらず剪断変 位量（限界愬断変位量）加一定の時に発生し，乙の值は 試験温度に依存している。そして限界剪断変位量の值に よってあ前述の3つの Type の破壊様相が明碓に区別す ることができる (Fig. 5 参照).

3）A-Type，B-Type 破壊をした場合，継手強度は溶 接部のど断面で考えるとほぼ溶接金属の顡断強度に等し い(Fig. 6 参照).一方 B-Type, C-Type 破壊をした 場合，継手強度を巨視的に破壊を生じた部分すなわち母 材断面で考えると，その強度は母材の大型 Deep Notch 武験結果よりあ低くなる (Fig. 7 参照). このことより剪 断力を受りる溶接継手では溶接部の寸法が，一見溶接部 とは無関係と考えられる材の低応力脆性破塄に著しい 影響を及ばすととがわかる。したかっって常温においては 構造的に重要視されないすみ肉溶接継手です低温におい てはその溶接部の破壊が重要楛造部材の破壊発生の引き 金になる可能性があるので十分注意を払っておく必要が あろう。

\section{参考文 献}

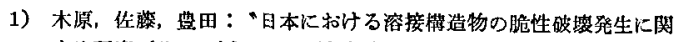
寸る研究 (その1)*, 本誌 42-2 (1973), pp. 69 90

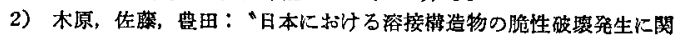
する研究 (その2)*，本誌 42-4 (1973) pp. 72 86

3）太田：“す吉肉溶接継手破㙥誉動の温度特性”本誌 34-7 (1965) pp. $68 \sim 688$ 